\title{
Production of domoic acidby diverse species of pennate diatoms
}

\author{
YUICHI KOTAKI \\ School of Fisheries Sciences, Kitasato University, Sanriku, Iwate 022-0101, Japan
}

SUMMARY: Pseudo-nitzschia multiseries produces a high level of domoic acid (DA) in culture. Significant amount of DA is also detected in $P$. seriata and $P$. australis, the latter of which causes massive death of sea lions and sea birds. On the other hand, a small amount of DA is detected in various species of Pseudonitzschia including those observed in the Japanese coastal waters. A low level of DA is also reported in a benthic species Amphora coffeaeformis. Recently, we have confirmed a significant level of DA production in a benthic diatom, which was identified as a new species Nitzschia navis-varingica. These facts show that DA distributes widely both in planktonic and benthic diatoms, though the level is different among the species. DA production of $P$. multiseries has been pointed out to be much affected by environmental bacteria. No DA is detected in these bacteria, suggesting that they are not involved directly in DA production of $P$. mutiseries. In contrast, DA production of the species with low or medium productivity was not affected much by bacteria.

\section{KEYWORDS: domoic acid, diatom, Pseudo-nitzschia, Nitzschia, bacteria, shellfish}

\section{INTRODUCTION}

The causative compound of amnesic shellfish poisoning (ASP) was traced to an excitatory amino acid, domoic acid (DA) $)^{1)}$. The toxin had been isolated from red alga Chondria armata as an anthelmintical compound $^{2)}$. As DA has the high affinity to ionotropic glutamate receptor, DA is recognized as an agonist of the natural transmitter, L-glutamic acid. Ionotropic glutamate receptor is classified as kainate, $\alpha$-amino-5methyl-3-hydroxyisoxazolen-4-propionate (AMPA) and $\mathrm{N}$-methyl-D-aspartate (NMDA) receptor subtypes based on amino acid sequence homology. Although DA shows affinity for all classes of ionotropic glutamate receptors, this toxin has a very high affinity for kainate receptors, intermediate affinity for AMPA receptors, and low affinity for NMDA receptors. Excess amount of DA flown into brain (e.g. hippocampus and amygdaloid nucleus) induces neurodegeneration resulting in memory loss, which is mediated by $\mathrm{Ca}^{2+}$ overload and inhibition of $\mathrm{Ca}^{2+}$ and calmodulin-stimulated adenylate cyclase ${ }^{3)}$.

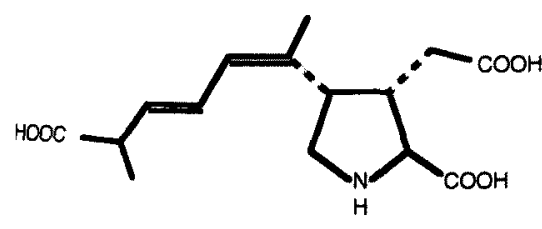

Domoic acid

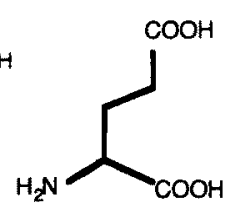

L-glutamic acid
Fig. 1 Structure of domoic acid and L-glutamic acid.
As DA producing-pennate diatoms were known to distribute widely in the world and relatively easy to culture, many series of culture experiment including ours were performed intensively for solving the DA production mechanism. In the present paper, DA production by diverse species of diatoms and studies on the production mechanism are discussed.

\section{DOMOIC ACID PRODUCING DIATOMS Genus Pseudo-nitzschia}

Pseudo-nitzschia multiseries was the first diatom identified as a causative microorganism of domoic acid in mussels responsible for ASP in Prince Edward Island, Canada in $1987^{4}$. $\quad$ P. australis was also identified as a producer of DA responsible for the deaths of sea bird (pelicans and cormorants) and sea lions, which ate DAcontaminated anchovies ${ }^{5,6,7)}$. Furthermore, $P$. seriata was identified as a DA producer by culture experiment ${ }^{8)}$. These three Pseudo-nitzschia are known to produce highest levels of $\mathrm{DA}^{9)}$. The remaining Pseudonitzschia including $P$. pseudodelicatissima and $P$. delicatissima were confirmed to produce DA, although not all isolates are toxic (Table 1).

ASP incident have never reported in Japan, however the presence of $P$. multiseries has been reported in Ofunato Bay, $\operatorname{Japan}^{15)}$. This led to investigate the screening of DA-producing Pseudo-nitzschia and DAcontaminated shellfish there. Every year since 1995, cultures of $P$. multiseries were established for the determination of DA, resulting in confirmation of high 
Table 1 Domoic acid producing pennate diatoms.

\begin{tabular}{lllll}
\hline \multicolumn{2}{c}{ Diatom } & DA level ${ }^{\star}$ & Country $^{\star 2}$ & Reference $^{\star 2}$ \\
\hline Pseudo-nitzschia & multiseries & High & Canada & [4] Bates et al. (1989) \\
& australis & High & USA & [10] Garrison et al. (1992) \\
& seriata & High & Denmark & [8] Lundholm et al. (1994) \\
& delicatissima & Low & New Zealand & [11] Rhodes et al. (1996) \\
& pseudodelicatissima & Low & Canada & [12] Martin et al. (1990) \\
& pungens & Low & New Zealand & [11] Rhodes et al. (1996) \\
& turgidula & Low & New Zealand & [11] Rhodes et al. (1996) \\
& fraudulenta & Low & New Zealand & [13] Rhodes et al. (1998) \\
& multistriata & Low & Italy & [14] Sarno \& Dahlmann(2000) \\
Pseudo-nitzschia & 4 other species & Low & Japan & Kotaki et al. (unpublished) \\
Pseudo-nitzschia & sp. (unidentified) ${ }^{* 3}$ & Low & Japan & Kotaki et al. (unpublished) \\
\hline Amphora & coffeaeformis & Low & Canada & [18]Shimizu et al. (1989) \\
\hline Nitzschia & navis-varingica & Medium & Vietnam & [19]Kotaki et al. (2000) \\
\hline
\end{tabular}

*1) Maximum domoic acid (DA) concentration of the diatom culture.

*2) First report.

High ; $>10$ pg/cell, Medium ; 1 10 pg/cell, Low ; $<1 \mathrm{pg} /$ cell

*3) Different from any Pseudo-nitzschia previously reported.

level of DA production in culture. DA was detected in wild mussel and scallop during November 1994 and February 1995, although the maximum DA level was 2.8 and $0.8 \mu \mathrm{g} / \mathrm{g}$ respectively, which is enough smaller than regulatory limit $(20 \mu \mathrm{g} / \mathrm{g})^{16)}$. However, no DA has been detected in these shellfish for 4 years thereafter. This suggests that $P$. multiseries has not bloomed as much as shellfish accumulate enough DA. Other 9 Pseudo-nitzschia species including $P$. pungens, $P$. pseudodelicatissima, $P$. delicatissima, and $P$. multistriata were also isolated and cultured, resulting in confirmation of the low DA productivity by HPLCfluorescence analysis ${ }^{17}$ (Table 1), although not all isolates were toxic, perhaps because of some difference in culture conditions (unpublished). These results show that many Pseudo-nitzschia species have an ability to produce DA, although DA production level differs among them. Physiological role of DA in these Pseudo-nitzschia species seems interesting but unsolved.

\section{Other genus}

Before our screening, only Amphora coffeaeformis was reported to produce small amount of $\mathrm{DA}^{18)}$, although negative result was obtained in another study ${ }^{4)}$. Recently a DA producing-pennate diatom was isolated from a shrimp culture pond in Vietnam ${ }^{19}$. The diatom was named as Nitzschia navis-varingica ${ }^{20)}$. Maximum DA level was ranged from 1.2 to 3.1 (Average 2.3) $\mathrm{pg} / \mathrm{cell}$. This DA level is lower than that of $P$. multiseries, but much higher than that of $A$. coffeaeformis $^{18)}$. Presence of this diatom was also confirmed in Japan (unpublished) as well as in Vietnam. This result together with that of Pseudo-nitzschia suggests that DA is produced not only by Pseudonitzschia but also by benthic diatom.

\section{CHARACTERISTICS AND MECHANISM OF DOMOIC ACID PRODUCTION}

In order to clarify DA production mechanism, culture experiments were conducted first for investigating the influencing factor on DA production in $P$. multiseries culture $^{4,21)}$. Among these investigations, two interesting DA production characteristics are focused here. 1) Significant increase of DA production is observed only at late stationary growth phase in batch culture where nutrients are used up and cells start starving. Low amount of DA is produced during exponential growth phase where nutrients are rich and cells grow actively. This indicates that $P$. multiseries produces DA significantly under starved conditions ${ }^{22}$ ) (Fig. 2). 2) DA production of $P$. multiseries is influenced much by environmental bacteria. As shown in Fig. 2, high level DA production is observed in nonaxenic culture, however the DA production decreases to less than 1/100 level when cultured under axenic conditions. In the culture reintroduced with bacteria, DA production level recovered drastically and sometimes exceeds the original level ${ }^{22)}$. This kind of 

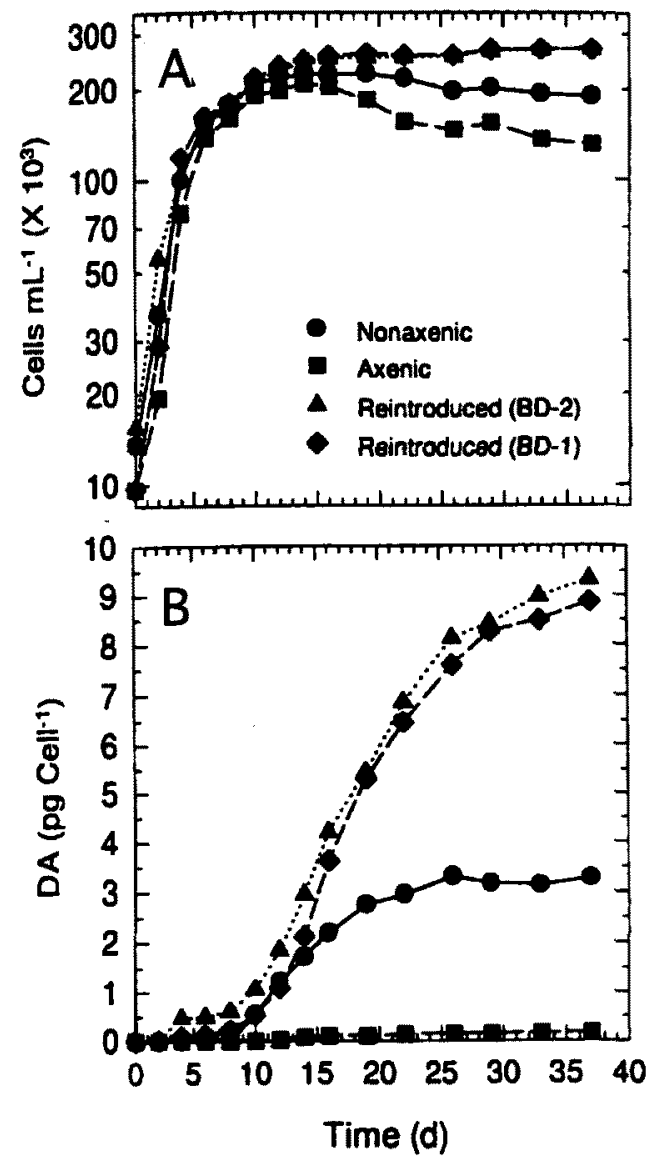

Fig. 2 Domoic acid production of $P$. multiseries in batch culture. Non-axenic (O); Axenic ( $\square$ ); Reintroduced with bacterial strain BD-2 ( $\mathbf{\Delta})$; Reintroduced with bacterial strain BD-1 ( $)$. Bates et al.: Natural Toxins, 3, 428-435 (1995) ${ }^{22)}$. John Wiley \& Sons Limited. Reproduced with permission.

bacterial influence on toxin production has not reported in any other toxin producing plankton. This influence is not exerted by all bacteria but by some limited bacteria. There might be a special relationship between $P$. multiseries and the bacteria on DA production. However, bacteria that have the influence are not limited to the bacteria isolated from the original culture. Bacteria isolated from other environment also show this influence ${ }^{22)}$. DA has never been detected from these bacteria, suggesting that bacteria are not involved directly in the production of $\mathrm{DA}^{9}$. However, to clarify the bacterial role on DA production seems important for elucidating the DA production mechanism of $P$. multiseries.

In order to re-confirm the bacterial influence on DA production of $P$. multiseries, DA amount per cell was investigated by culture experiment using non-axenic and axenic culture. Similar bacterial influence was observed as reported by Bates et al. ${ }^{22)}$. Bacterial influence on DA production was also investigated in cultures of $N$. navis-varingica, $P$. cuspidata, and $P$. pseudodelicatissima. In case of $N$. navis-varingica, maximum cellular DA (1.7 pg/cell) observed in nonaxenic culture decreased to about half in axenic culture $^{19)}$. Reintroducing to an axenic culture with the bacteria induced no remarkable enhancement of DA production, while the bacteria induced remarkable enhancement in the $P$. multiseries culture experiment described above. In case of the rest 2 Pseudo-nitzschia cultures, remarkable bacterial influence on DA production was not observed either (unpublished). These results suggest that environmental bacteria influence DA production of pennate diatoms with much difference in the influencing levels among diatom species. Especially, $P$. multiseries that produces high level of DA is suggested to be alive with strong relationship to environmental bacteria.

Supposed biosynthesis of DA was suggested by culture experiment of axenic $P$. multiseries using ${ }^{13} \mathrm{C}$ and ${ }^{14} \mathrm{C}$ labeled sodium acetate ${ }^{23)}$. Analysis of the labeling pattern indicated that DA is biosynthesized by condensation of an isoprenoid intermediate with another intermediate derived from the tricarboxylic acid (TCA) cycle, probably $\alpha$-ketoglutarate. To solve the relationship between the biosynthesis procedure of DA and the bacterial influence on DA production might help us to clarify the role of DA in diatoms.

\section{REFERENCES}

1. Wright J L C, Boyd RK, deFreitas ASW, et al. Identification of domoic acid, a neuroexcitatory amino acid, in toxic mussels from eastern Prince Edward Island. Can. J. Chem. 1989; 67:481 - 490.

2. Takemoto T, Daigo K. Constituents of Chondria armata.. Chem. Pharm. Bull. 1958; 6:578 - 580.

3. Nijjar MS, Nijjar SS. Domoic acid-induced neurodegeneration resulting in memory loss is mediated by $\mathrm{Ca}^{2+}$ overload and inhibition of $\mathrm{Ca}^{2+}+$ calmodulinstimulated adenylate cyclase in rat brain. Int. J. Mol. Med. 2000; 6:377-389.

4. Bates SS, Bird CJ, deFreitas ASW, et al. Pennate diatom Nitzschia pungens as the primary source of domoic acid, a toxin in shellfish from eastem Prince Edward Island, Canada. Can. J. Fish. Aquat. Sci. 1989; 46:1203 - 1215.

5. Fritz L, Quilliam MA, Wright ILC, Beale AM, Work TM. An outbreak of domoic acid poisoning attributed to the pennate diatom Pseudonitzschia australis. J. Phycol. 1992; 28:439 - 442.

6. Work TM, Beale AM, Fritz L, et al. Domic acid intoxication of brown pelicans and cormorants in Santa Cruz, California. In: Smayda TJ, Shimizu Seds. Toxic Phytoplankton Blooms in the Sea. Amsterdam, 
1993: $643-649$.

7. Scholin CA, Gulland F, Doucette GJ, et al. Mortality of sea lions along the central California coast linked to a toxic diatom bloom. Nature 2000; 403:80-84.

8. Lundholm N, Skov J, Pocklington R, Moestrup $O$. Domoic acid, the toxic amino acid responsible for amnesic shellfish poisoning, now in Pseuodonitzschia seriata (Bacillariophyceae) in Europe. Phycologia 1994; 33:475 - 478.

9. Bates SS. Ecophysiology and metabolism of ASP toxin production. In: D. M. Anderson ADC, G. M. Hallegraeff, ed. Physiological Ecology of Harmful Algal Blooms. Berlin Heidelberg: Springer-Verlag, 1998:405 426.

10. Garrison DL, Conrad SM, Eilers PP, Waldron EM. Confirmation of domoic acid production by Pseudonitzschia australis (Bacillariophyceae) cultures. J. Phycol. 1992; 28:604 - 607.

11. Rhodes L, White D, Syhre M, Atkinson M. Pseudonitzschia species isolated from New Zealand coastal waters: Domoic acid production in vitro and links with shellfish toxicity. In: Yasumoto T, Oshima Y, Fukuyo Yeds. Harmful and Toxic Algal Blooms. Paris: Intergovermental Oceanographic Commission of UNESCO, $1996: 155$ - 158.

12. Martin J, Haya K, Burridge LE, Wildish DJ. Nitzschia pseudodelicatissima - a source of domoic acid in the Bay of Fundy, eastern Canada Mar. Ecol. Prog. Ser. 1990; 67:177- 182 .

13. Rhodes L, Scholin C, Garthwaite I. Pseudo-nitzschia in New Zealand and the role of DNA probes and immunoassays in refining marine biotoxin monitoring programmes. Natural Toxins 1998; 6:105 - 111.

14. Samo D, Dahlman J. Production of domoic acid in another species of Pseudo-nitzschia: P. multistriata in the Gulf of Naples (Mediterranean sea). Harmful Algal News 2000;21: 5 .

15. Takano $\mathrm{H}$, Kuroki $\mathbf{K}$. Some diatoms in the section Pseudonitzschia found in coastal waters of Japan. Bull. Tokai Reg. Fish. Res. Lab. 1977; 91:41 - 51.

16. Kotaki Y, Koike K, Sato S, Ogata T, Fukuyo Y, Kodama M. Confirmation of domoic acid production of Pseudonitzschia multiseries isolated from Ofunato Bay, Japan. Toxicon 1999; 37:677 - 682 .

17. Pocklington R, Milley JE, Bates SS, Bird CJ, deFreitas ASW, Quilliam MA. Trace determination of domoic acid in seawater and phytoplankton by high-performance liquid chromatography of the fluorenylmethoxycarbonyl (FMOC) derivative. Intern. J. Environ. Anal. Chem. 1990; 38:351 - 368.

18. Shimizu Y, Gupta S, Masuda K, Maranda L, Walker CK, Wang R. Dinoflagellate and other microalgal toxins: Chemistry and biochemistry. Pure \& Appl. Chem. 1989; 61:513 - 516 .
19. Kotaki Y, Koike K, Yoshida M, et al. Domoic acid production in Nitzschia sp. (Bacillariophyceae) isolated from a shrimp-culture pond in Do Son, Vietnam. $J$. Phycol. 2000; 36:1057-1060.

20. Lundholm N, Moestrup O. Morphology of the marine diatom Nitzschia navis-varingica, sp. nov. (Bacillariophyceae), another producer of the neurotoxin domoic acid. J. Phycol. 2000; 36:1162-1174.

21. Pan Y, Bates SS, Cembella AD. Environmental stress and domoic acid production by Pseudo-nitzschia: a physiological perspective. Natural Toxins 1998;6:127 135.

22. Bates SS, Douglas DJ, Doucette GJ, Leger C. Enhancement of domoic acid production by reintroducing bacteria to axenic cultures of the diatom Pseudo-nitzschia multiseries. Natural Toxins 1995;3:428 - 435.

23. Ramsey UP, Douglas DJ, Walter JA, Wright JC. Biosynthesis of domoic acid by the diatom Pseudonitzschia multiseries. Natural Toxins 1998; 6:137 - 146. 